\title{
PENENTUAN TIPOLOGI KAWASAN RAWAN GEMPABUMI UNTUK MITIGASI BENCANA DI KECAMATAN PANGALENGAN \\ KABUPATEN BANDUNG
}

\author{
Oleh : Yakub Malik*)
}

\begin{abstract}
Abstrak
Kecamatan pangalengan di Kabupaten Bandung adalah salah satu wilayah yang mengalami kerusakan cukup parah akibat gempa bumi yang terjadi 2 September 2009 dengan episentrum di selatan Tasikmalaya. Dampaknya terlihat di beberapa tempat mengalami kerusakan bangunan mulai dari tingkatan hancur sampai rusak ringan. Berdasarkan kejadian tersebut terdapat permasalahan yang dapat dikaji mengapa Kecamatan Pangalengan mengalami kerusakan cukup parah dibandingkan dengan kecamatan lain yang berdekatan.

Setelah di kaji ternyata kondisi fisik lahan Kecamatan Pangalengan secara geologis rawan terhadap ancaman bencana gempa bumi. Berdasarkan penilaian "land capabilty rating " termasuk lahan kurang stabil dengan tipologi kawasan rawan bencana gempa bumi tipe C (Kepmen PU No.21 Tahun 2007) terdapat lebih dari 2 faktor yang saling melemahkan. Jenis batuan dengan sifat fisik lemah, dekat dengan zona sesar, kemiringan lereng curam dan intensitas gempa tinggi.

Selain kondisi lahan rawan secara geologis, faktor sosial turut memberikan andil terhadap tingkat kerusakan, yaitu kondisi rumah tidak ramah gempa, pola pemukiman mengelompok, tingkat kepadatan penduduk dan pengetahuan masyarakat tentang bencana yang masih kurang. Untuk mengurangi resiko bencana di masa yang akan datang perlu meningkatkan kesiapsiagaan masyarakat dan penataan kawasan Pangalengan pasca terjanya bencana berbasis mitigasi bencana.
\end{abstract}

Kata kunci: tipologi kawasan, rawan gempabumi, mitigasi bencana.

*) Ir. Yakub Malik, M.Pd. adalag dosen Jurusan Pendidikan Geografi FPIPS-UPI.

\section{Pendahuluan}

Secara geografis Indonesia terletak di daerah katulistiwa dengan morfologi yang beragam dari daratan sampai pegunungan tinggi. Keragaman morfologi ini banyak dipengaruhi oleh faktor geologi terutama dengan adanya aktivitas pergerakan lempeng tektonik aktif di sekitar perairan Indonesia diantaranya adalah lempeng Eurasia, Australia dan lempeng Dasar Samudera Pasifik. Pergerakan lempeng-lempeng tektonik tersebut menyebabkan terbentuknya jalur gempabumi, rangkaian gunung api aktif serta patahan-patahan yang dapat berpotensi menjadi sumber gempa 
Sejumlah peristiwa bencana gempa bumi dengan magnitude besar akhirakhir ini sering terjadi di beberapa wilayah Indonesia, seperti gempabumi dan tsunami di Aceh pada tanggal 26 Desember2004, di Pulau Nias pada tanggal 28 Maret 2005, di Yogyakarta pada tanggal 27 Mei 2006, di Pangandaran 17 Juli 2006, di Tasikmalaya 2 September 2009 dan gempabumi Padang 30 September 2009.

Jawa Barat termasuk salah satu wilayah yang memliki kerawanan bencana tinggi, kondisi ini dipengaruhi oleh tatanan geologi yang kompleks sehingga rawan dengan bencana geologi gempa bumi Berdasarkan catatan sejarah gempabumi merusak di Indonesia yang disusun oleh Pusat Vulkanologi dan Mitigasi Bencana Geologi (DVMBG) di wilayah Jawa Barat pernah terjadi sedikitnya 29 kali bencana gempabumi dengan kategori merusak terutama yang bersumber di darat sejak tercatat tahun 1883 sampai sekarang. Sebagian dari daerah-daerah yang rawan mengalami bencana geologi gempabumi berada pada wilayah padat penduduk seperti Bogor, Cianjur, Pelabuhanratu-Sukabumi, RajamandalaPadalarang, Ciamis-Kuningan Sumedang-Majalengka, Tasikmlaya, Bandung dan hampir seluruh wilayah pegunungan Jawa Barat Selatan.

Karakteristik gempabumi di Jawa Barat sebagian besar bukan dari zona subduksi/zona penunjaman, akan tetapi dari patahan/sesar aktif di darat. Gempabumi yang bersumber dari sesar aktif di darat sangat berpotensi merusak meskipun magnetudonya tidak terlalu besar, namun kedalamannya dangkal dan dekat dengan pemukiman dan aktivitas manusia.

Gempabumi sampai saat ini belum dapat diperkirakan saat kejadiannya kapan, dimana dan berapa besarannya. Dapat terjadi siang hari pada saat kita bekerja ataupun malam pada saat sedang tidur lelap, sehingga tidak dapat menyelamatkan diri karena kejadiannya berlangsung sangat cepat tertimpa runtuhan bangunan,longsoran bukit ataupun tersapu badai tsunami.

Upaya untuk mengurangi dampak bencana yaitu dengan melakukan kegiatan yang disebut Mitigasi Bencana sebagaimana tercantum dalam UU Nomor 24 Tahun 2007 Tentang Penanggulangan Bencana untuk menghadapi kemungkinan bencana yang akan datang. Salah satu bentuk mitigasi untuk meminimisasi dampak korban gempabumi yaitu dengan mengetahui karakteristik setiap wilayah untuk mengetahui tingkat kerawanannya terhadap bencana, sebagai pedoman penataan ruang kawasan rawan bencana gempabumi sebagaimana yang tercantum dalam UU No. 26 Tahun 2007 Tentang Penataan Ruang.

\section{Rumusan Masalah}

Kejadian gempabumi 2 September 2009 7,2 Skala Rihter dengan episentrum di sebelah selatan Tasikmalaya getarannya dirasakan kuat di beberapa wilayah Jawa Barat bagian selatan seperti Tasikmlaya, Garut, Cianjur, Bandung dan sekitarnya. Salah satu wilayah di Kabupaten Bandung yang mengalami kerusakan yang cukup parah yaitu Kecamatan Pangalengan, dampaknya terlihat di beberapa tempat mengalami kerusakan bangunan mulai dari tingkatan hancur sampai rusak ringan. Berdasarkan kejadian tersebut terdapat permasalahan yang 
dapat dikaji mengapa Kecamatan Pangalengan mengalami kerusakan cukup parah dibandingkan dengan kecamatan lain yang berdekatan. Untuk mengetahuinya terlebih dahulu perlu mengetahui :

(1) Bagaimana kondisi fisik lahan Kecamatan Pangalengan dan sekitarnya ?

(2) Bagaimana tingkat dan sebaran kerusakan bangunan akibat gempabumi Tasikmalaya di Kecamatan Pangalengan?

(3) Bagaimana tipologi kawasan rawan gempabumi Kecamatan Pangalengan dan sekitarnya?

\section{Tujuan Penelitian}

Tujuan yang Ingin dicapai dari penelitian ini adalah :

1) Mengidentifikasi dampak kerusakan, khususnya banggunan akibat kejadian gempabumi Tasikmalaya 2 September 2009.

2) Mengidentifikasi faktor fisik dan sosial yang menimbulkan kerawanan wilayah Kecamatan Pangalengan terhadap gempabumi.

3) Menentukan tipologi kerawanan gempabumi untuk mitigasi bencana di Kecamatan Panagalengan

\section{Metode Penelitian}

Metoda penelitian yang digunakan adalah survey dengan melakukan observasi atau kunjungan lapangan untuk memperoleh data primer di lapangan gambaran fisik dan sosial daerah yang mengalami kerusakan akibat gempabumi Tasikmalaya. Pengkajian data sekunder dari literatur yang terkait dengan permasalahan yang dikaji, berupa dokumen regulasi, hasil-hasil penelitian sebelumnya yang terkait dengan lokasi penelitian, interpretasi dan analisis Peta Geologi, Peta Rupa Bumi, dan Citra Satelit.

\section{Tinjauan Pustaka}

Untuk menentukan tipologi suatu kawasan yang rawan terhadap bencana gempa bumi berdasarkan acuan Undang-Undang No. 24 Tahun 2007 Tentang Penaggulangan Bencana, Undang-Undang No 26 Tahun 2007 Tentang Penataan Ruang dan Keputusan Menteri Pekerjaan Umum No. 21 /PRT/M/2007 Tentang Pedoman Penataan Ruang Kawasan Rawan Letusan Gunung Berapi dan Gempa Bumi. Penetapan kawasan rawan gempa bumi didasarkan pada hasil pengkajian terhadap daerah yang diindikasikan berpotensi bencana atau lokasi yang diperkirakan akan terjadi bencana atau dampak bencana

Pengkajian untuk menetapkan apakah suatu kawasan dinyatakan rawan terhadap gempa bumi membutuhkan data pendukung kondisi fisik lahan seperti jenis batuan, struktur geologi, kemiringan lereng dan kemantapan tanah. Kondisi sosial masyarakat seperti jumlah penduduk, struktur penduduk, pola pemukiman dan kualitas rumah/bangunan. Data-data tersebut saling melengkapi dalam menetapkan suatu kawasan rawan bencana gempa bumi dan tsunami

Karakteristik fisik tipe kawasan rawan gempa bumi ditentukan berdasarkan tingkat risiko gempa yang didasarkan pada informasi geologi dan penilaian 
kestabilan (cara perhitungan lihat tabel, sudah disederhanakan). Berdasarkan hal tersebut, maka kawasan rawan gempa bumi dapat dibedakan menjadi (6) enam tipe kawasan yang diuraikan sebagai berikut:

(1). Tipe A

Kawasan ini berlokasi jauh dari daerah sesar yang rentan terhadap getaran gempa. Kawasan ini juga dicirikan dengan adanya kombinasi saling melemahkan dari faktor dominan yang berpotensi untuk merusak. Bila intensitas gempa tinggi (Modified Mercalli Intensity / MMI VIII) maka efek merusaknya diredam oleh sifat fisik batuan yang kompak dan kuat.

(2). Tipe B

Faktor yang menyebabkan tingkat kerawanan bencana gempa pada tipe ini tidak disebabkan oleh satu faktor dominan, tetapi disebabkan oleh lebih dari satu faktor yang saling mempengaruhi, yaitu intensitas gempa tinggi (MMI VIII) dan sifat fisik batuan menengah. Kawasan ini cenderung mengalami kerusakan cukup parah terutama untuk bangunan dengan konstruksi sederhana.

(3). Tipe C

Terdapat paling tidak dua faktor dominan yang menyebabkan kerawanan tinggi pada kawasan ini. Kombinasi yang ada antara lain adalah intensitas gempa tinggi dan sifat fisik batuan lemah; atau kombinasi dari sifat fisik batuan lemah dan berada dekat zona sesar cukup merusak. Kawasan ini mengalami kerusakan cukup parah dan kerusakan bangunan dengan konstruksi beton terutama yang berada pada jalur sepanjang zona sesar.

(4). Tipe D

Kerawanan gempa diakibatkan oleh akumulasi dua atau tiga faktor yang saling melemahkan, kawasan dengan kemiringan lereng curam, intensitas gempa tinggi dan berada sepanjang zona sesar merusak; atau berada pada kawasan dimana sifat fisik batuan lemah, intensitas gempa tinggi, di beberapa tempat berada pada potensi landaan tsunami cukup merusak. Kawasan ini cenderung mengalami kerusakan parah untuk segala bangunan dan terutama yang berada pada jalur sepanjang zona sesar.

(5). Tipe E

Kawasan ini merupakan jalur sesar yang dekat dengan episentrum yang dicerminkan dengan intensitas gempa yang tinggi, serta di beberapa tempat berada pada potensi landaan tsunami merusak. Sifat fisik batuan dan kelerengan lahan juga pada kondisi yang rentan terhadap goncangan gempa. Kawasan ini mempunyai kerusakan fatal pada saat gempa.

(6). Tipe F

Kawasan ini berada pada kawasan landaan tsunami sangat merusak dan di sepanjang zona sesar sangat merusak, serta pada daerah dekat dengan episentrum dimana intensitas gempa tinggi. Kondisi ini diperparah dengan sifat fisik batuan lunak yang terletak pada kawasan morfologi curam sampai dengan sangat curam yang tidak kuat terhadap goncangan gempa. Kawasan ini mempunyai kerusakan fatal pada saat gempa. 
Untuk menentukan tipologi suatu kawasan rawan bencana gempa bumi dengan cara melakukan skoring, yaitu perkalian antara "pembobotan" dengan "nilai kemampuan", dan dari hasil perkalian tersebut dibuat suatu rentang nilai kelas yang menunjukkan nilai kemampuan lahan didalam mengahadapi bencana alam kawasan rawan gempa bumi. Dari hasil perkalian tersebut maka dapat dibuat "land capability ratings" atau tingkat kemampuan lahan sebagai berikut:

Tabel 1. Skoring untuk menentukan tipologi kawasan rawan bencana

\begin{tabular}{|c|c|c|}
\hline $\begin{array}{c}\text { KLASIFIKASI } \\
\text { KESTABILAN }\end{array}$ & $\begin{array}{c}\text { RENTANG } \\
\text { SKOR }\end{array}$ & $\begin{array}{c}\text { TIPOLOGI } \\
\text { KAWASAN }\end{array}$ \\
\hline \multirow{2}{*}{ Stabil } & $30-40$ & $\mathrm{~A}$ \\
\cline { 3 - 3 } & & $\mathrm{B}$ \\
\hline \multirow{2}{*}{ Kurang Stabil } & \multirow{2}{*}{$41-50$} & $\mathrm{C}$ \\
\hline \multirow{2}{*}{ Tidak Stabil } & \multirow{2}{*}{$50-60$} & $\mathrm{D}$ \\
\cline { 3 - 3 } & & $\mathrm{F}$ \\
\hline
\end{tabular}

Sumber : Peraturan Mentri PU No.21

Tabel 2. Matriks pembobotan untuk kestabilan wilayah terhadap kawasan rawan gempa bumi komponen (informasi geologi) yang diperhitungkan

\begin{tabular}{|c|c|c|c|c|c|c|c|}
\hline NO. & INFORMASI GEOLOGI & \multicolumn{3}{|c|}{ KELAS INFORMASI } & $\begin{array}{c}\text { NILAI } \\
\text { KEMAMPUAN }\end{array}$ & ВОВОТ & SKOR \\
\hline \multirow[t]{4}{*}{1} & \multirow[t]{4}{*}{$\begin{array}{l}\text { Geologi (sifat fisik dan } \\
\text { keteknikan batuan) }\end{array}$} & \multicolumn{3}{|c|}{$\begin{array}{l}\text { Andesit, granit, diorit, metaamorf, breksi volkanik, } \\
\text { aglomerat, breksi sedimen, konglomerat }\end{array}$} & 1 & \multirow{4}{*}{3} & 3 \\
\hline & & \multicolumn{3}{|c|}{$\begin{array}{l}\text { Batupasir, tufa kasar, batulanau, arkose, greywacke, } \\
\text { batugamping }\end{array}$} & 2 & & 6 \\
\hline & & \multicolumn{3}{|c|}{ Pasir, lanau, batulumpur, napal, tufa halus, serpih } & 3 & & 9 \\
\hline & & \multicolumn{3}{|c|}{ Lempung, lumpur, lempung organik, gambut } & 4 & & 12 \\
\hline \multirow[t]{4}{*}{2} & \multirow[t]{4}{*}{ Kemiringan Lereng } & \multicolumn{3}{|c|}{ Datar - Landai $(0-7 \%)$} & 1 & \multirow{4}{*}{3} & 3 \\
\hline & & \multicolumn{3}{|c|}{ Miring - Agak Curam (7 - 30\%) } & 2 & & 6 \\
\hline & & \multicolumn{3}{|c|}{ Curam - Sangat Curam $(30-140 \%)$} & 3 & & 9 \\
\hline & & \multicolumn{3}{|c|}{ Terjal $(>140 \%)$} & 4 & & 12 \\
\hline \multirow[t]{5}{*}{3} & \multirow{5}{*}{ Kegempaan } & MMI & $\alpha$ & Richter & & \multirow{5}{*}{5} & \\
\hline & & I, ii, iii, iv, v & $<0,05 \mathrm{~g}$ & $<5$ & 1 & & 5 \\
\hline & & Vi, vii & $0,05-0,15 g$ & $5-6$ & 2 & & 10 \\
\hline & & Viii & $0,15-0,30 \mathrm{~g}$ & $6-6,5$ & 3 & & 15 \\
\hline & & $\mid x, x, x i, x i i$ & $>0,30 \mathrm{~g}$ & $>6,5$ & 4 & & 20 \\
\hline \multirow[t]{3}{*}{4} & \multirow[t]{3}{*}{ Struktur Geologi } & \multicolumn{3}{|c|}{ Jauh dari zona sesar } & 1 & \multirow{3}{*}{4} & 4 \\
\hline & & \multicolumn{3}{|c|}{$\begin{array}{l}\text { Dekat dengan zona sesar ( } 100 \text { - } 1000 \mathrm{~m} \text { dari zona } \\
\text { sesar) }\end{array}$} & 2 & & 8 \\
\hline & & \multicolumn{3}{|c|}{ Pada zona sesar (<100 m dari zona sesar) } & 4 & & 16 \\
\hline
\end{tabular}

Sumber : Peraturan Mentri PU No 21 Th.2007

Untuk mengukur nilai kemampuan yang diberikan dalam zonasi ini adalah dari angka 1 hingga 4 . Nilai 1 adalah nilai tertinggi suatu wilayah terhadap 
kemampuannya untuk stabil terhadap bencana geologi. Nilai 4 adalah nilai untuk daerah yang tidak stabil terhadap bencana alam geologi. Pembobotan yang diberikan dalam zonasi ini adalah dari angka 1 hingga 5. Nilai 1 memberikan arti tingkat kepentingan informasi geologi yang sangat tinggi, artinya informasi geologi tersebut adalah informasi yang paling diperlukan untuk mengetahui zonasi bencana alam. Nilai 5 adalah bobot informasi geologi yang dianggap sangat rendah kepentingannya untuk mengukur suatu zonasi kawasan rawan bencana

\section{Hasil Penelitian dan Pembahasan}

\section{a. Kondisi Fisik Wilayah Pangalengan Dan Sekitarnya}

Pangalengan adalah sebuah kecamatan yang terletak bagian selatan Kabupaten Bandung, Berdasarkan koordinatnya berada pada $07^{\circ} 07^{\prime} 00$ " LS sampai $07^{0} 18^{\prime} 00^{\prime \prime}$ LS dan $107^{0} 30^{\prime} 00^{\prime \prime}$ BT sampai $107^{0} 38^{\prime} 00^{\prime \prime}$ BT. Terdiri dari 13 desa atau kelurahan yaitu Banjarsari, Lamajang, Margaluyu, Margamekar, Margamukti, Margamulya, Pangalengan, Pulosari, Sukaluyu, Sukamanah, Tribaktimulya, Wanasuka, dan Warnasari. Adapun batas administrative Kecamatan Pangalengan yaitu 1) Sebelah utara : Kecamatan Cimaung 2) Sebelah selatan : Kecamatan Talegong 3) dan Kecamatan Bungbulang 4) Sebelah timur : Kecamatan Kertasari 4) Sebelah barat : Kecamatan Pasir Jambu (Gambar 1).

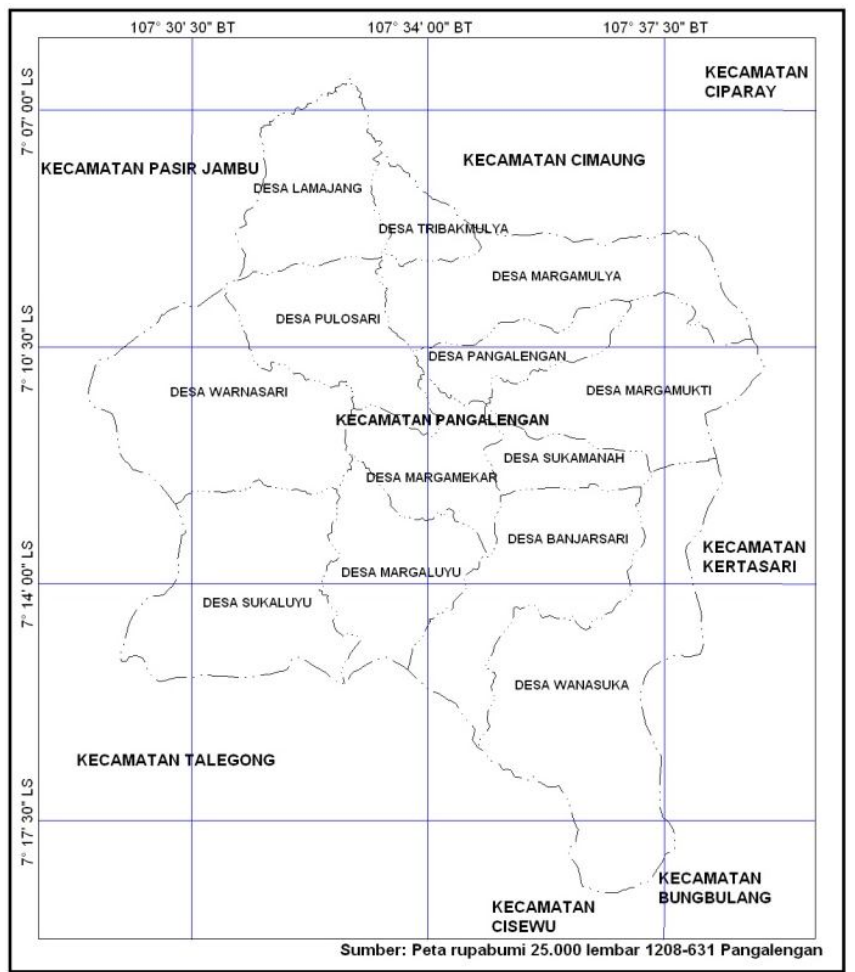

Gambar 1. Peta Administratif Kecamatan Pangalengan

Kecamatan Pangalengan secara umum merupakan bagian dari fisiografi bentang alam daerah Bandung Selatan, terdiri dari perbukitan ,pegunungan dan 
dataran tinggi,. kawasan pegunungan mempunyiai sebaran paling luas yang dapat terlihat dari citra satelit. Morfologi Kecamatan Pangalengan merupakan dataran tinggi (1400 m) yang sempit dikelilingi oleh pegunungan seperti Gunung Malabar (2321 m), Gunung Tilu (2042 m), Gunung Wayang (2182 m), dan Gunung Windu (2054 m). Kemiringan lereng daerah Kecamatan Pangalengan berdasarkan interpretasi peta topografi beragam mulai dari landai (>8\% - 15\%) sampai curam (>25\% - 40\%). Adapu desa-desa yang relatif curam ialah desa Margaluyu, desa Margamukti, dan Desa Margamulya, Pemanfaatan lahan kawasan Pangalengan merupakan areal pertanian holtikultura, perkebunan teh dan kina, obyek wisata Situ Cileunca, mata air panas cibolang dan Pembangkit Listrik Tenaga Panas Bumi/ Geothermal (PLTG) Wayang - Windu.

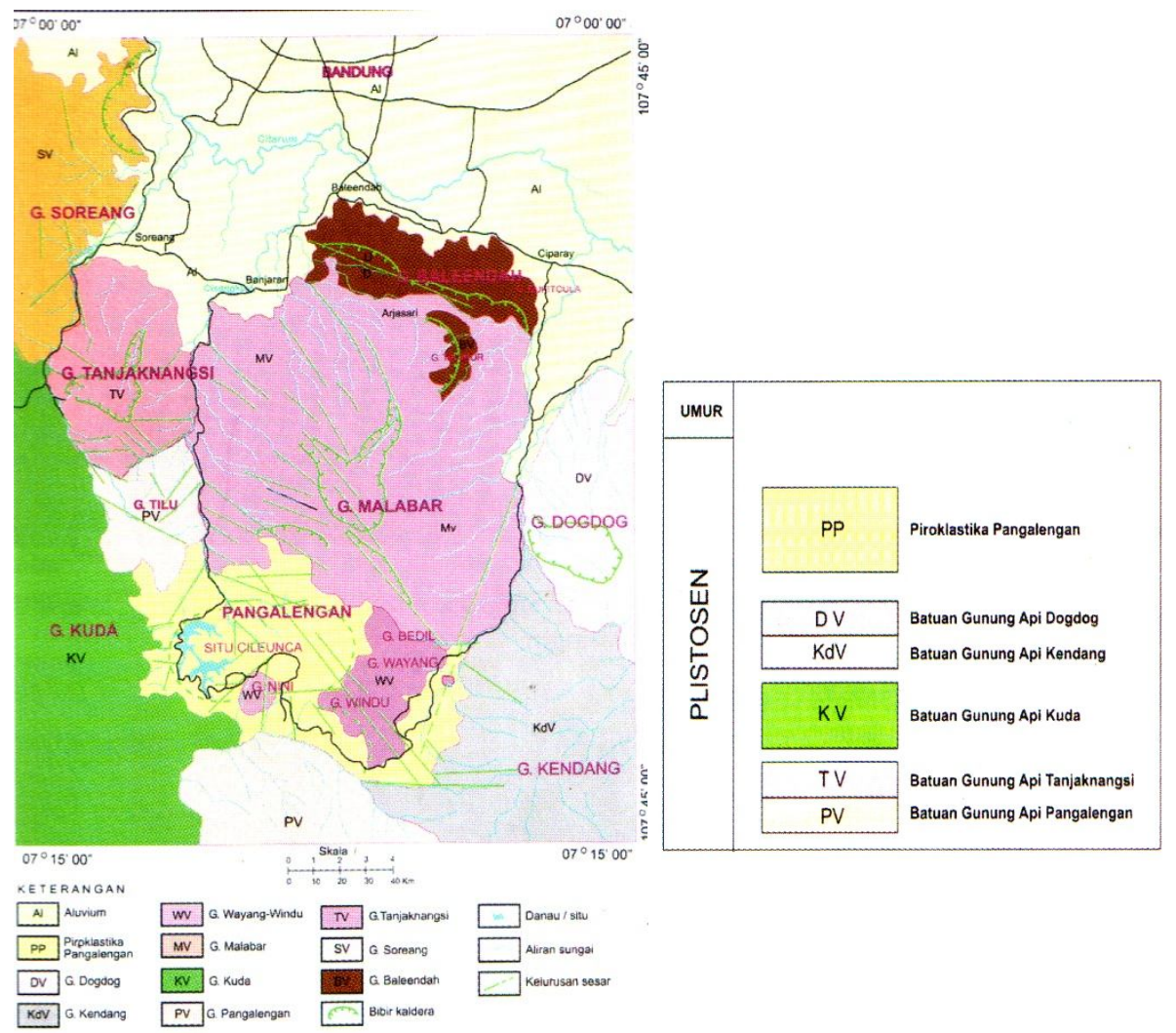

Gambar 2. Peta Geologi dan Stratigrafi Regional Bandung Selatan (Sillitongga, 1973)

Kondisi geologi Kecamatan Pangalengan dan sekitarnya, berdasarkan analisis peta geologi lembar garut dan Pameungpeuk (Alzwar drr, 1992), peta geologi daerah Bandung Selatan (Silitonga, 1973) batuan yang menyusunya berasal dari hasil erupsi/ endapan piroklastik Gunung Pangalengan purba yang meletus besar (katalismik) menghasilkan suatu dataran Pangalengan dengan Situ Cileunca sebagai bekas Kalderanya (Sutikno bronto drr, 2006), kemudian ditutupi oleh produk gunung berapi /endapan piroklastik yang berasal dari gunung berapi parasiter yang muncul di sekelilingnya yaitu Gunung Windu, Gunung Wayang dan 
Gunung Malabar yang berumur lebih muda Kuarter Atas (Pistosen) dengan sifat fisik batuan umumnya masih lepas-lepas. Struktur geologi yang berkembang di wilayah Kecamatan pangalengan berdasarkan analisis peta geologi di atas terlihat sebagai kelurusan-kelurusan sesar yang berarah tenggara-barat laut (Gambar 2)

\section{b. Dampak kerusakan bangunan}

Dampak kerusakan bangunan akibat gempa bumi Tasikmalaya pada tanggal 2 September 2009 di Kecamatan Pangalengan melputi hampir seluruh desa, terdiri dari 22.292 kepala keluarga (KK) korban yang rumahnya mengalami kerusakan dari rusak ringan sampai mengalami kehancuran (Tabel 3). Bangunan/rumah yang mengalami kerusakan umumnya terbuat dari tembok/permanen yang tidak diperkuat dengan struktur yang memadai. Sebaran rumah/bangunan yang mengalami kerusakan paling parah yaitu terdapat di Desa Margamukti, Pangalengan, Margamulya, Margamekar dan Desa Sukamanah. (Gambar 3)

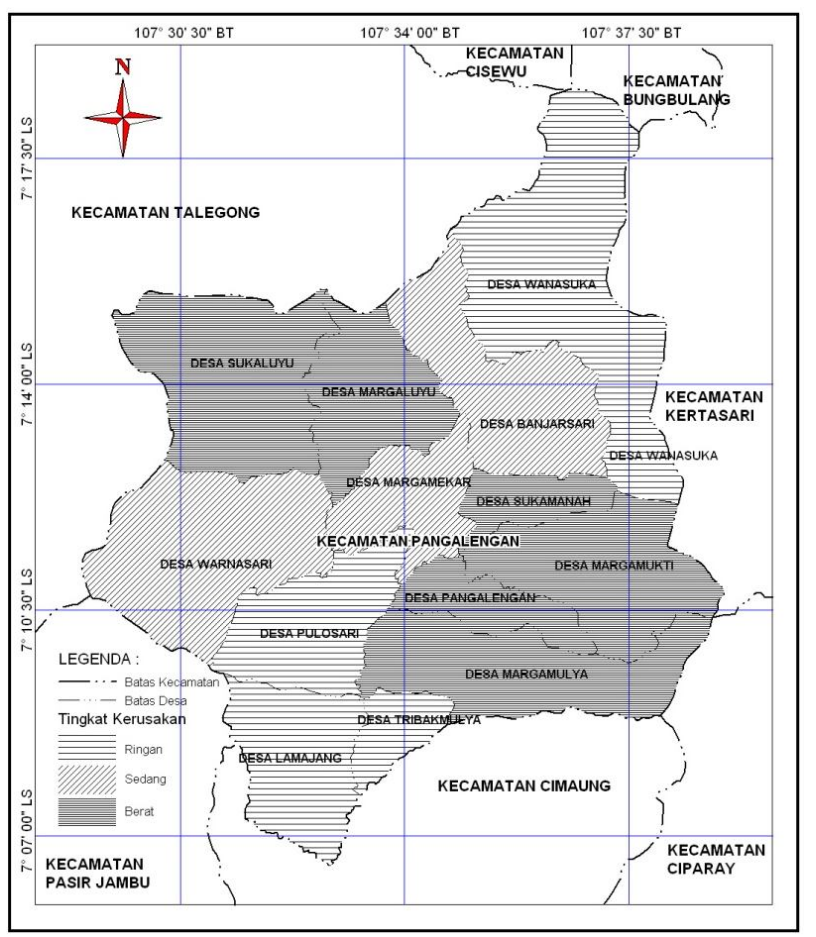

Gambar 3. Peta Zona Kerusakan Bangunan di Kecamatan Pangalengan

\section{c. Kerawanan Fisik Lahan Kecamatan Pangalengan}

Faktor-faktor yang mempengaruhi kerawanan wilayah Kecamatan Pangalengan terhadap bencana gempa bumi disebabkan oleh lebih dari 2 faktor yang saling melemahkan, yaitu :

(1) Kondisi jenis batuan yang menutupinya endapan hasil aktivitas gunung berapi/ endapan piroklastik berumur Plistosen dengan sifat fisik batuan belum mengalami konsolidasi (lemah), sehingga jika terjadi gempa bumi efek 
rusaknya tidak dapat diredam, sehingga dampaknya akan menimbulkan kerusakan yang lebih parah.

(2) Struktur geologi terdapat kelurusan-kelurusan sesar yang berarah tengara-barat laut, diperkirakan terdapat sesar yang memotong Kaldera-Malabar yang mengakibatkan bentuk perbukitan terpotong-potong membentuk gawir (sesar Gunung Tilu - Malabar). Struktur geologi merupakan pencerminan seberapa besar suatu wilayah mengalami "deraan" tektonik. Semakin rumit struktur geologi yang berkembangdi suatu wilayah, maka menunjukkan bahwa wilayah tersebut cenderung sebagai wilayah yang tidak stabil.

(3) Morfologi perbukitan dengan kemiringan dari landai sampai curam terlihat dari citra satelit Kemiringan lereng dapat memberikan gambaran tingkat stabilitas terhadap kemungkinan terjadinya longsoran atau runtuhan tanah dan batuan, terutama pada saat terjadi kawasan rawan gempa bumi. Semakin terjal lereng maka potensi untuk terjadinya gerakan tanah dan batuan akan semakin besar, walaupun jenis batuan yang menempatinya cukup berpengaruh untuk tidak terjadinya longsoran.

(4) Intensitas gempa bumi cukup tinggi karena dekat dengan episentrum kegempaan Jawa Barat bagian selatan. Faktor kegempaan merupakan informasi yang menunjukkan tingkat intensitas gempa, baik berdasarkan skala Mercalli, anomali gaya berat, maupun skala Richter Semakin kecil angka faktor kegempaan yang tercantum pada suatu wilayah, maka intensitas kawasan rawan gempa bumi di wilayah tersebut akan semakin kecil dan wilayah akan lebih stabil, begitupun sebaliknya.

Berdasarkan hasil skoring wilayah Kecamatan Pangalengan berada pada rentang > 40-50, artinya termasuk klasifikasi kawasan kurang stabil dengan tipologi kerawanan bencana gempa bumi tipe $\mathrm{C}$.

Tabel 3.Tingkat Kerusakan Bangunan di Kecamatan Pangalengan

\begin{tabular}{|c|l|c|c|c|c|}
\hline \multirow{2}{*}{ NO } & \multirow{2}{*}{ DESA } & JML & \multicolumn{3}{|c|}{ KERUSAKAN BANGUNAN } \\
\cline { 4 - 6 } & & KK & HANCUR & BERAT & RINGAN \\
\hline 1 & WANASUKA & 318 & 6 & 40 & 272 \\
\hline 2 & BANJARSARI & 617 & 23 & 180 & 414 \\
\hline 3 & MARGALUYU & 1813 & 129 & 332 & 1251 \\
\hline 4 & SUKALUYU & 1278 & - & 431 & 827 \\
\hline 5 & WARNASARI & 659 & 12 & 172 & 475 \\
\hline 6 & PULOSARI & 552 & 84 & 143 & 325 \\
\hline 7 & MARGAMEKAR & 1.025 & 121 & 338 & 666 \\
\hline 8 & SUKAMANAH & 3.530 & 270 & 1.184 & 2076 \\
\hline 9 & MARGAMUKTI & 3.241 & 462 & 1.245 & 1.534 \\
\hline 10 & PANGALENGAN & 4.957 & 428 & 1.664 & 2865 \\
\hline 11 & MARGAMULYA & 3.514 & 257 & 902 & 2355 \\
\hline 12 & TRIBAKTIMULYA & 442 & 21 & 124 & 290 \\
\hline 13 & LAMAJANG & 346 & 6 & 80 & 260 \\
\hline & JUMLAH & 22.292 & 1.819 & 6.735 & 13730 \\
\hline
\end{tabular}

Sumber :Satkorlak Kecamatan Pangalengan 2009.

Tabel 4. Skoring tipologi kawasan rawan bencana gempa bumi 
di Kecamatan Pangalengan

\begin{tabular}{|c|c|c|c|c|}
\hline No & $\begin{array}{c}\text { Karakaterisik } \\
\text { Wilayah }\end{array}$ & $\begin{array}{c}\text { Nilai } \\
\text { Kemampuan }\end{array}$ & Bobot & Skor \\
\hline 01 & $\begin{array}{c}\text { Batuan Piroklastik } \\
\text { (lemah /urai) }\end{array}$ & 3 & 3 & 9 \\
\hline 02 & Dekat Zona Sesar & 2 & 4 & 8 \\
\hline 03 & $\begin{array}{c}\text { Topografi Landai - } \\
\text { Curam }\end{array}$ & 2 & 3 & 6 \\
\hline 04 & Intensitas Gempa Tinggi & 4 & 5 & 20 \\
\hline & Jumlah & & & 43 \\
\hline
\end{tabular}

Sumber : Data lapangan 2009

\section{d. Kerawanan Sosial - Masyarakat Di Kecamatan Pangalengan.}

Kecamatan Pangalengan berdasarkan tipologi kawasan rawan bencana gempa bumi termasuk tipe $\mathrm{C}$, artinya kondisi lahan tidak stabil rawan terhadap bencana gempa bumi, cenderung akan mengalami kerusakan berat terutama desa/pemukiman yang berdekatan dengan zona/jalur sesar, selain itu ada beberapa hal yang menyebabkan Kecamatan Pangalengan mengalami kerusakan berat yaitu :

(1) Ketidaktahuan masyarakat mengenai kebencanaan. Masyarakat tidak tahu bagaimana tindakan tepat yang harus dilakukan apabila terjadi bencana gempa sehingga menimbulkan kepanikan yang dapat menimbulkan lebih banyak korban.

(2) Ketidakpahaman masyarakat mengenai kondisi fisik lokasi tempat tinggal. Sebagian besar masyarakat Desa Pangalengan tidak mengetahui kondisi fisik lokasi tempat tinggal yang labil dan rawan terhadap bencana sehingga tidak ada antisipasi atau mitigasi yang dilakukan untuk menghadapi bencana gempa bumi.

(3) Kondisi fisik bangunan yang permanen dan tidak ramah terhadap gempa. Sebagian besar kondisi bangunan Desa Pangalengan adalah permanen dengan struktur tulang kurang memadai, hanya sedikit saja kondisi rumah yang semi permanen dan panggung. Kondisi rumah yang permanen akan lebih mudak rusak ketika tertimpa bencana gempa apabila dibandingkan dengan rumah panggung.

(4) Pola permukiman yang tidak teratur dan sangat padat. Hal ini terlihat dari hasil pengamatan, pola permukiman tidak memiliki pola yang baik dan tidak terorganisir dengan baik. Jarak antar bangunan sangat sempit sehingga apabila suatu bangunan runtuh akibat bencana gempa tidak menutup kemungkinan akan menimpa rumah di dekatnya.

(5) Jumlah penduduk dan kepadatannya. Desa Pangalengan memiliki jumlah penduduk paling banyak apabila debandingkan dengan desa-desa lain yang ada di Kecamatan Pangalengan. Begipun dengan kepadatan penduduk, Desa Pangalengan termasuk desa yang padat penduduk sehingga memungkinkan lebih banyak korban saat terjadi gempa.

\section{Penutup}


Dari hasil kajian dan pembahasan, bahwa kerawanan bencana gempa bumi di Kecamatan Pangalengan karena kondisi lahan yang secara geologis terbangun dari jenis batuan vulkanik (endapan piroklastik) yang sifat fisiknya lemah,dilalui oleh sesar atau dekat dengan zona sesar, morfologi perbukitan dengan kemiringan lereng dari landai - curam dan dekat dekat episentrum gempa bumi Jawa Barat bagian selatan dengan intensitas tinggi.

Kerawanan sosial, kondisi masyarakat yang belum memahami tentang bencana gempa karena sebelumnya belum pernah mengalami gempa bumi dengan guncangan yang kuat (magnitude yang besar), kondisi bangunan gedung yang tidak diperkuat dengan struktur tulang beton yang memadai, pola pemukiman padat dan mengelompok karena keterbatasan lahan yang relatif datar, dan penyuluhan tentang bencana khususnya gempa bumi yang kurang dari pihak pemerintah daerah setempat sehingga belum ada kesiapsiagaan dalam menghadapi bencana.

Untuk mitigasi bencana gempa bumi di Kecamatan Pangalengan perlu sosialisasi agar masyarakat mengetahui bahwa daerahnya rawan bencana gempa bumi, rumah/bangunan seyogianya dirancang ramah gempa dengan biaya yang terjangkau, penataan kawasan pasca bencana menyesuaikan dengan arahan pemanfaatan ruang sesuai pedoman penataan ruang kawasan rawan bencana gempa bumi Kepmen PU No.21 Tahun 2007. Dan lebih penting adalah mengurangi dampak dari bencana itu sendiri dengan menyiapkan masyarakat 'membiasakan diri' hidup bersama dengan bencana, khususnya untuk lingkungan yang sudah (terlanjur) terbangun, yaitu dengan mengembangkan system peringatan dini dan memberikan pedoman bagaimana mempersiapkan diri dalam menghadapi bencana yang biasa terjadi, sehingga masyarakat dapat merasakan keamanan serta kenyamanan dalam kehidupannya.

\section{Daftar Pustaka}

Anonim, Undang - Undang No. 26 Tahun 2007 Penataan Ruang.

Anonim, Undang - Undang No.24 Tahun Tentang Penanggulangan Bencana.

Anonim, Keputusan Mentri Pekerjaan Umum No.21 Tahun 2007 Tentang Pedoman Penataan Ruang Kawasan Rawan Bencana Letusan Gunung Berapi Dan Gempa Bumi. Jakarta: Departemen Pekerjaan Umum, Direktorat Jendral Penataan Ruang.

Anonim, Citra Satelit Pangalengan, http://www. Geospasial, bnpb. Go.id .diakses Februari 2010.

Alzwar, M ., Akbar., dan Bahcri, S., 1992. Peta Geologi Lembar Garut Dan

Pameungpeuk, Jawa. Skala 1 ; 100.000. Bandung: Pusat Penelitian Dan Pengembangan Geologi.

Bronto, S., 2006. Stratigrafi Gunungapi Daerah Bandung Selatan, Jawa Barat. Jurnal Geologi Indonesia, 1, h.89-101.

Brahmantyo, Budi, dan Supartoyo, 2007. Menghadapi Ketidaktentuan Datangnya Bencana. Warta Geologi, 2, h.4 -7. 
Silitonga, P.H., 1973. Peta Geologi Lembar Bandung, Jawa Skala 1 ; 100.000. Bandung: Direktorat Geologi. 